\title{
Physiological energetics of Mytilus edulis: Scope for Growth
}

\author{
J. Widdows ${ }^{1}$, D. Johnson ${ }^{2}$ \\ ${ }^{1}$ Plymouth Marine Laboratory (West Hoe), Prospect Place, The Hoe, Plymouth PL1 3DH, United Kingdom \\ ${ }^{2}$ Water Research Centre, Environment Laboratory, Henley Road, Medmenham, Marlow, Buckinghamshire SL7 2HD, United \\ Kingdom
}

\begin{abstract}
Mussels Mytilus edulis were sampled during the GEEP Workshop from 4 field sites in Langesundfjord, Norway, and from 4 experimental groups exposed to a range of water-accommodated diesel oil and copper concentrations in a mesocosm study. Measurements of physiological responses such as feeding rate, food absorption efficiency, respiration rate and excretion rate - were integrated by means of the energy balance equation, and performance was assessed in terms of 'scope for growth'. The results show a significant decline in scope for growth, both along the pollution gradient in Langesundfjord and with increasing exposure to copper and diesel oil in the mesocosm experiment. Feeding rate was the primary component of the energy budget that accounted for the decline in scope for growth with increasing pollution.
\end{abstract}

\section{INTRODUCTION}

The measurement of physiological traits, such as rates of feeding, digestion, respiration and excretion, and their integration by means of physiological energetics, can provide insight into the growth process and how it might be disrupted by environmental stress and pollution (Bayne \& Newell 1983). Determination of the energy available for growth, based on the physiological analysis of the energy budget rather than the 'direct' measurement of growth itself, has proved to be particularly useful in assessing the biological effects of pollution (Widdows 1983, Widdows et al. 1987). The 'direct' measurement of growth and production is difficult in many species, especially bivalve molluscs, because (a) a large proportion of the total production can be lost in the form of gametes (either in a single complete release or by gradual spawning), (b) it is impracticable to measure weight changes in animals with shells and with variable amounts of seawater, and (c) it is not sufficient to measure changes in shell length because there is no apparent tight coupling between shell growth and tissue growth (Hilbish 1986). There is, however, evidence of good agreement between indirect estimates of growth based on the energy budget and the more direct determinations of production based on detailed population size-class analysis (Gilfillan \& Vandermeulen 1978, Bayne \& Worrall 1980).

Measurement of the energy available for growth, termed scope for growth, provides a rapid and quantitative assessment of the energy status of the animal as well as insight into the individual components (and mechanism of toxicity) which affect changes in growth rate (Widdows 1985a). The measurement of changes in physiological energetics of individual animals should form an important component of any toxicological or environmental monitoring programme, for it represents an integration of the wide variety of possible cellular responses (both detrimental and beneficial). Growth rate is an overall measure of performance that is readily interpretable (beneficial when increased or detrimental when decreased) and related to ecological consequences at the population and community levels of organization.

The main objective of this contribution to the GEEP Workshop was to use the procedures of physiological energetics to quantify the sublethal biological effects along an environmental pollution gradient and in response to a range of exposure conditions in a controlled mesocosm experiment. The latter enabled a more direct comparison of the various biological effects techniques for the assessment of pollution effect (i.e. 
from cellular to community levels of organisation). This study used the mussel Mytilus edulis as an indicator species, and the physiological approach included measurement of the mussel's condition (state variables such as nitrogen quotient and body condition index), its performance (rate variables such as growth) and the efficiency with which it functions (such as growth efficiency).

\section{MATERIALS AND METHODS}

Mesocosm study. Details of the mesocosm experiment carried out at Solbergstrand Experimental Station, Oslofjord (Norway), can be found in Bakke et al. (1988). Three mesocosm basins were dosed with differing concentrations (L: low, $\mathrm{M}$ : medium, $\mathrm{H}$ : high) of a copper and hydrocarbon mixture (Table 1), with a fourth basin acting as a control (C). Sixteen Mytilus edulis, of similar shell dimensions were sampled from one experimental basin per day and their physiological responses were determined over a period of $10 \mathrm{~h}$. Each group of mussels was coded so that measurements were carried out 'blind' (i.e. without knowledge of their origin). Mussels were maintained and measured in seawater pumped from the appropriate mesocosm basins ( $\mathrm{C}, \mathrm{L}, \mathrm{M}$ or $\mathrm{H}$ ). The seawater, originating from 40 m water depth, had a salinity of $34 \%$, a temperature of $9{ }^{\circ} \mathrm{C}$, and a relatively low seston concentration (seston $0.70 \mathrm{mg} \mathrm{l}^{-1} \pm 0.07 \mathrm{SE}$, particulate organic matter 0.27 $\mathrm{mg} \mathrm{l^{-1 }} \pm 0.03 \mathrm{SE}$ ).

Field study. Details of field sampling in Langesundfjord, Norway, can be found in Follum \& Moe (1988). Physiological measurements were carried out ('blind') on 2 groups of mussels per day. Mussels were sampled from 2 field sites and were held air exposed in insulated containers for about $7 \mathrm{~h}$ during transportation to Sol-

Table 1. Concentrations of total aromatic hydrocarbons (THC measured by fluorescence in diesel oil equivalents, mean \pm $\mathrm{SE}, n=10$ ) and copper ( $\mathrm{Cu}$, nominal values), in the water of mesocosm basins. Tissue concentrations of selected polyaromatic hydrocarbons (PAH, mean \pm semi-range, $n=2$ ) and copper $(\mathrm{Cu})$ in Mytilus edulis. Sampling date 4 Aug 86, after $15 \mathrm{wk}$ exposure ( $3 \mathrm{wk}$ for $\mathrm{H}$ mussels); figures in brackets: estimated concentrations at time of physiological measurements (11 Aug 86 for $H$ mussels)

\begin{tabular}{|c|c|c|c|c|}
\hline \multirow[b]{2}{*}{ Basin } & \multicolumn{2}{|c|}{$\begin{array}{l}\text { Concentration } \\
\text { in water } \\
\left(\mu \mathrm{g} \mathrm{l}^{-1}\right)\end{array}$} & \multicolumn{2}{|c|}{$\begin{array}{l}\text { Concentration } \\
\text { in tissues } \\
\text { (mg kg-1 dry wt) }\end{array}$} \\
\hline & THC & $\mathrm{Cu}$ & PAH & $\mathrm{Cu}$ \\
\hline $\mathrm{C}$ & $3.0 \pm 0.7$ & $(0.5)$ & $1.1 \pm 0.1$ & 7.3 \\
\hline $\mathrm{L}$ & $6.4 \pm 0.6$ & 0.8 & $6.2 \pm 0.2$ & 16.3 \\
\hline$M$ & $31.5 \pm 7.2$ & 5.0 & $22.8 \pm 0.2$ & 26.8 \\
\hline $\mathrm{H}$ & $124.5 \pm 20.7$ & 20.0 & $10.7 \pm 1.6(14)$ & 59.0 \\
\hline
\end{tabular}

Table 2. Mytilus edulis. Shell length, tissue weight and body condition index of mussels from the mesocosm basins and field sites (Langesundfjord); means $\pm \mathrm{SE}, n=16$

\begin{tabular}{|cccc|}
\hline Source & $\begin{array}{c}\text { Shell length } \\
(\mathrm{cm})\end{array}$ & $\begin{array}{c}\text { Tissue wt } \\
(\mathrm{dry} w \mathrm{w}, \mathrm{g})\end{array}$ & $\begin{array}{c}\text { Condition } \\
\text { index }\end{array}$ \\
\hline Basin & & & \\
C & $5.57 \pm 0.05$ & $1.64 \pm 0.13$ & $108 \pm 10$ \\
L & $5.25 \pm 0.03$ & $1.05 \pm 0.08$ & $73 \pm 4$ \\
M & $5.54 \pm 0.06$ & $1.06 \pm 0.10$ & $69 \pm 7$ \\
H & $5.09 \pm 0.07$ & $1.08 \pm 0.08$ & $91 \pm 3$ \\
Site & & & \\
1 & $5.06 \pm 0.05$ & $0.76 \pm 0.06$ & $71 \pm 6$ \\
2 & $5.20 \pm 0.04$ & $0.85 \pm 0.07$ & $74 \pm 4$ \\
3 & $5.18 \pm 0.04$ & $0.83 \pm 0.06$ & $71 \pm 3$ \\
4 & $4.96 \pm 0.05$ & $0.56 \pm 0.03$ & $77 \pm 5$ \\
\hline
\end{tabular}

bergstrand Experimental Station. Sixteen mussels of uniform shell dimensions (ca $5 \mathrm{~cm}$ shell length, Table 2) were selected from each group. They were cleaned of epibionts, washed, dried and labelled. Due to the extended period of aerial exposure they were allowed $1.5 \mathrm{~h}$ to recover in water (i.e. to repay oxygen debt, flush out ammonia accumulated in the mantle cavity water and tissues, and resume normal feeding) before commencement of physiological measurements (clearance rate, food absorption efficiency, respiration and excretion rates). Mussels from the field sites were maintained in flowing seawater pumped from $1 \mathrm{~m}$ depth in the Oslofjord $\left(17^{\circ} \mathrm{C}, 33.5 \%\right.$, seston concentration $1.34 \mathrm{mg} \mathrm{l}^{-1} \pm 0.07 \mathrm{SE}$ and particulate organic matter $0.66 \mathrm{mg} \mathrm{l}^{-1} \pm 0.03 \mathrm{SE}$ ). Clearance and respiration rates of 16 individuals from both groups were measured within a period of $6 \mathrm{~h}$. Seston and faeces were also sampled during this period, whereas ammonia excretion rates were measured the following day.

Feeding rate measurement. Clearance rate, defined as volume of water cleared of particles animal ${ }^{-1} \mathrm{~h}^{-1}$, was estimated by measuring the removal of suspended particles from water flowing through experimental chambers containing individual mussels. The clearance rate measuring system consisted of a centrifugal pump discharging water into a mixing chamber (1.5 I volume) with a magnetic stirrer and thence via $2.5 \mathrm{~mm}$ bore tubing through 18 chambers in parallel (16 experimental and 2 control chambers without mussels). The inflow into each chamber was at the bottom, adjacent to the mussel's inhalent mantle edge, and the outflow was via an overflow tube at the top thus minimizing recirculation of water by the mussel. Flow rates through each chamber were maintained constant at ca $180 \mathrm{ml} \mathrm{min}{ }^{-1}$. Accurate estimates of clearance rate are only achieved by using appropriate flow rates; low enough to record a significant difference between the 
inflow and outflow particle concentration, yet sufficient to prevent any significant recirculation of water by the mussel. The appropriate flow rates required will depend on the size and geometry of the experimental chamber and the clearance rate of the mussel, which will vary with body size and physiological and environmental conditions. However, as a general guide flow rates through each chamber of the system described here should be approximately 2 to 3 times the clearance rate of the mussels (i.e. the particle concentration in the outflow should not be less than $50 \%$ of the inflow concentration). Mussels were placed in the experimental chambers and were left undisturbed for 60 min to allow their valves to open, and feeding to be resumed.

Water samples were collected simultaneously from the outflows of all chambers and particle concentrations were measured by an electronic particle counter (Coulter Counter Model D) using a $140 \mu \mathrm{m}$ orifice tube (mean of 4 counts per sample). The sensitivity settings of the Coulter Counter were adjusted so that only particles $>2 \mu \mathrm{m}$ were counted. Water sampled from the control chamber represented the inflow concentration $\left(C_{1}\right)$ and water sampled from the outflow of each experimental chamber represented the outflow concentration $\left(C_{0}\right)$. Clearance rate $\left(\mathrm{l} \mathrm{h}^{-1}\right)$ was then calculated as flow rate multiplied by $\left(C_{1}-C_{0}\right) / C_{r}$. The clearance rate of each mussel was determined after 60 , 100 and $140 \mathrm{~min}$. All water entering the clearance-rate measuring system was pre-filtered through a $180 \mu \mathrm{m}$ sieve to remove copepods, larvae and large debris.

Food absorption efficiency. Absorption efficiency was measured by the ratio method of Conover (1966); it represents the efficiency with which organic material is absorbed from the ingested food material (seston). This method depends upon the assumption that only the organic component of food is significantly affected by the digestive processes and compares the proportion of organic matter in the food and the faeces. The Conover ratio is:

$$
\text { absorption efficiency }=(F-E) /[(1-E) F]
$$

where $F=$ ash-free dry weight:dry weight ratio of food (seston); $E=$ ash-free dry weight:dry weight ratio of the faeces. The amount of suspended particulate material or seston concentration $\left(\mathrm{mg} \mathrm{l}^{-1}\right)$ in the inflowing water was sampled in triplicate at ca 3 hourly intervals. A known volume of water ( 4 to 7 l) was filtered through washed, ashed and pre-weighed glass fibre filters $(4.7 \mathrm{~cm}, \mathrm{GFC})$ and the salts washed out of the filter and filter edges with distilled water $(3 \times 10$ $\mathrm{ml}$ ). Filters were dried at $90^{\circ} \mathrm{C}$ and weighed in order to calculate the total dry weight of particulate matter per litre of seawater. They were then ashed for $3 \mathrm{~h}$ at $450^{\circ} \mathrm{C}$ in a muffle furnace and weighed again in order to calculate the weight of organic material combusted. This component represents the weight of particulate organic matter (POM) or ash-free material. In spite of handling GFC filters with forceps and storing in desiccators, GFC filters show small and occasionally significant changes in weight, presumably due to daily changes in humidity and atmospheric conditions. Consequently, blank GFC filters were weighed at each stage for each batch of filters in order to correct for weight change.

Faeces were collected by pipette from the chambers of the clearance-rate measuring system and filtered onto washed, ashed and pre-weighed glass fibre filters (GFC). Salts were then washed out of the filters with distilled water $(3 \times 10 \mathrm{ml})$ and the filters dried at $90^{\circ} \mathrm{C}$ and weighed before ashing at $450^{\circ} \mathrm{C}$. Faecal production was relatively low, due to low seston concentrations in the water from Oslofjord, therefore faeces from paired individuals were pooled $(n=8)$.

Respiration rate. Rates of oxygen consumption by individual mussels were measured simultaneously in 8 closed glass respirometers (modified Quickfit flasks, volume $500 \mathrm{ml}$ ) held in a temperature controlled water bath. Air-saturated seawater was added to each respirometer and stirred by means of a magnetic stirrer bar beneath a perforated glass plate supporting a mussel. The rate of decline in oxygen partial pressure $\left(\mathrm{pO}_{2}\right)$ in each chamber was measured by a Radiometer oxygen electrode (E5046) connected to a Strathkelvin oxygen meter (Model 781). Each of the 8 oxygen meters was coupled to a multichannel chart recorder. Thirty min were allowed for the mussels to open their shell valves and to resume pumping, then oxygen uptake was measured over the next hour. Oxygen consumption was not measured below a partial pressure of about $100 \mathrm{~mm} \mathrm{Hg}$ because the rate of $\mathrm{O}_{2}$ uptake by Mytilus edulis and other oxyconforming species becomes dependent on external $\mathrm{pO}_{2}$ at lower oxygen tensions. The rate of oxygen consumption ( $V_{\mathrm{O}_{2}}$, $\mathrm{ml} \mathrm{O}_{2} \mathrm{~h}^{-1}$ ) was calculated as follows

$$
V_{\mathrm{O}_{2}}=60\left[C\left(t_{0}\right)-C\left(t_{1}\right)\right]\left(V_{\mathrm{r}}-V_{\mathrm{a}}\right) /\left(t_{1}-t_{0}\right)
$$

where $t_{0}, t_{1}=$ start and finish times (min) of the measurement period; $C(t)=$ concentration of oxygen in the water $\left(\mathrm{ml} \mathrm{O} \mathrm{O}_{2} \mathrm{1}^{-1}\right)$ at time $t_{i} V_{\mathrm{r}}=$ volume of the respirometer; $V_{\mathrm{a}}=$ volume of the animal. Oxygen solubility tables were used to convert $\mathrm{pO}_{2}$ values to oxygen concentration in $\mathrm{ml} \mathrm{O}_{2} \mathrm{l}^{-1}$.

Ammonia excretion. The rate of ammonia excretion was determined by placing individual mussels in 200 $\mathrm{ml}$ of air-saturated filtered seawater (GFC filters). Following a $3 \mathrm{~h}$ incubation period in a water bath, water samples were taken from each experimental chamber, and from a control chamber without a mussel, and analysed (in duplicate) for ammonia using the 
phenol-hypochlorite method (for details see Widdows 1985b). Ammonia excretion was expressed in terms of $\mu g \mathrm{NH}_{4}$ excreted per hour.

Calculation of scope for growth. Physiological rates were converted to mass-specific rates for mussels of $1 \mathrm{~g}$ dry weight using appropriate weight exponents (b) in the allometric equation (clearance rate $b=0.4$, oxygen consumption $b=0.65$, ammonia excretion $b=0.65$ ). Individual physiological responses were converted into energy equivalents and used in the balanced energy equation:

$$
\mathrm{C}=\mathrm{P}+\mathrm{R}+\mathrm{U}+\mathrm{F}
$$

where $\mathrm{C}=$ total consumption of food energy; $\mathrm{P}=$ production of both somatic tissue and gametes; $\mathrm{R}=$ respiratory energy expenditure; $U=$ energy lost as excreta; $F=$ faecal energy loss. The absorbed ration, $\mathrm{A}$, is the product of consumption, $\mathrm{C}$, and the efficiency of absorption of energy from the food. Production may then be expressed as

$$
\mathrm{P}=\mathrm{A}-(\mathrm{R}+\mathrm{U})
$$

i.e. production, $P$, is estimated from the difference between energy absorbed from the food and the energy expenditure via respiration and excretion; it may be referred to as 'scope for growth' (SFG).

Calculation of C, A, R and $U$ (all $\mathrm{J} \mathrm{g}^{-1} \mathrm{~h}^{-1}$ ) is as follows

$$
\begin{gathered}
\mathrm{C}=\text { clearance rate }\left(\mathrm{l} \mathrm{g}^{-1} \mathrm{~h}^{-1}\right) \times \operatorname{POM}\left(\mathrm{mg} \mathrm{l}^{-1}\right) \\
\times 23 \mathrm{Jg}^{-1} \text { ash-free dry weight, } \\
\mathrm{A}=\mathrm{C} \times \text { absorption efficiency, } \\
\mathrm{R}=V_{\mathrm{O}_{2}}\left(\mathrm{ml} \mathrm{O}_{2} \mathrm{~g}^{-1} \mathrm{~h}^{-1}\right) \times 20.33 \mathrm{~J} \mathrm{ml}^{-1} \mathrm{O}_{2}, \\
\mathrm{U}=\mathrm{mg} \mathrm{NH}_{4} \mathrm{~g}^{-1} \mathrm{~h}^{-1} \times 19.4 \mathrm{~J} \mathrm{mg}^{-1} \mathrm{NH}_{4} .
\end{gathered}
$$

Growth efficiency $\left(k_{2}\right)$ is the efficiency with which food is converted to body tissues; it is equivalent to scope for growth per unit of absorbed energy (Widdows 1985b).

Body condition index. This index has traditionally been used by shellfisheries biologists to quantify bivalve condition, mainly in terms of temporal changes but also in terms of spatial changes (Widdows 1985a). It is easily determined and was therefore included in the physiological measurements carried out at the workshop. The body condition index based on dry tissue weight (g) was calculated as follows

$$
\mathrm{BCI}=1000(\text { Dry tissue } \mathrm{wt}) /(\text { Shell cavity volume })
$$

Shell cavity volume (ml) represents the total displacement volume of a completely closed mussel, minus displacement volume of the shell, after opening the mussel and removing the body tissues. Dry tissue weight was determined by drying the soft tissues in pre-weighed containers to constant weight $(24 \mathrm{~h})$ at $90^{\circ} \mathrm{C}$

\section{RESULTS}

\section{Mesocosm study}

Physiological responses of Mytilus edulis exposed to the 4 experimental conditions - control, low, medium and high dose (C, L, M and H) - are presented in Table 3. There was a decline in clearance rate with exposure to increasing concentrations of petroleum hydrocarbons and copper. The maximum and mean of 3 clearance rate estimates per individual mussel are presented in Table 3 ; they show the same inverse relationship with increasing exposure; mean rates were consistently 0.3 to $0.4 \mathrm{lg}^{-1} \mathrm{~h}^{-1}$ below maximum recorded rates, and the variance estimates were similar. There was no significant difference between clearance rates of $\mathrm{C}$ and $\mathrm{L}$ exposed mussels, but those exposed to the $M$ condition had significantly lower clearance rates $(80 \%$ of the control group, $p<0.05)$. Mussels exposed to the $\mathrm{H}$ dose only partially opened their shell valves; they had very low clearance rates, less than $20 \%$ of the control group, and did not produce faecal material. Mean food absorption efficiency for mussels from $C, L$ and $M$ conditions was $0.401 \pm$ $0.06 \mathrm{SE})$.

Rates of oxygen consumption by Mytilus edulis from $C, L$ and $M$ exposed groups were not significantly different, whereas the mean respiration rate of those from the $\mathrm{H}$ dose group was very low $(p<0.01)$, due to the partially closed state of the majority of individuals in the respirometers. Consequently, the total energy expenditure of $\mathrm{H}$ exposed mussels was probably under-estimated by the respirometric measurements due to a contribution from anaerobic metabolism.

Rates of ammonia excretion and the nitrogen quotient for mussels from $\mathrm{C}, \mathrm{L}$ and $\mathrm{M}$ exposed groups were all similar. Ammonia excretion rates by $\mathrm{H}$ dose mussels were very low and significantly lower than in the controls $(p<0.01)$, primarily due to the partial closure of the mussels.

Table 4 lists energy equivalents of the physiological responses, including scope for growth (SFG) of mussels exposed to the 4 experimental conditions. There was a marked decline in SFG and growth efficiency with exposure to increasing concentrations of petroleum hydrocarbons and copper. However, the decline in SFG was not statistically significant for $L$ dose mussels, but was significant for $\mathrm{M}$ dose $(p<0.05)$ and $\mathrm{H}$ dose individuals $(p<0.01)$.

By contrast, Table 2 shows that the condition indices of mussels from the 4 basins did not follow the pattern of dosing, with mussels from the $\mathrm{L}$ and $\mathrm{M}$ basins being similar but having lower indices than those from $C$ and $\mathrm{H}$ basins.

Concentrations of copper and selected aromatic hy- 
Table 3. Mytilus edulis. Physiological responses in mussels exposed to 4 concentrations of petroleum hydrocarbons and copper in experimental mesocosm basins and in mussels collected from 4 sites in Langesundfjord (mean $\pm \mathrm{SE}, n=16$ )

\begin{tabular}{|c|c|c|c|c|c|}
\hline Source & \multicolumn{2}{|c|}{ Clearance rate $\left(\mathrm{lg}^{-1} \mathrm{~h}^{-1}\right)$} & $\begin{array}{c}\text { Respiration } \\
\left(\mathrm{ml} \mathrm{O} \mathrm{O}^{-1} \mathrm{~h}^{-1}\right)\end{array}$ & $\begin{array}{c}\text { Ammonia excretion } \\
\left(\mu g \mathrm{NH}_{3} \mathrm{~g}^{-1} \mathrm{~h}^{-1}\right)\end{array}$ & $\begin{array}{l}\text { Nitrogen } \\
\text { quotients }\end{array}$ \\
\hline \multicolumn{6}{|l|}{ Basin } \\
\hline $\mathrm{C}$ & $3.34 \pm 0.12$ & $3.02 \pm 0.12$ & $0.228 \pm 0.019$ & $19.00 \pm 2.31$ & $0.090 \pm 0.009$ \\
\hline $\mathrm{L}$ & $3.22 \pm 0.19$ & $2.80 \pm 0.17$ & $0.227 \pm 0.013$ & $14.57 \pm 1.16$ & $0.099 \pm 0.006$ \\
\hline$M$ & $2.79 \pm 0.14^{\circ}$ & $2.33 \pm 0.14^{\circ}$ & $0.232 \pm 0.048$ & $20.54 \pm 2.09$ & $0.090 \pm 0.006$ \\
\hline $\mathrm{H}$ & $0.63 \pm 0.06 \cdots$ & $0.36 \pm 0.04 \cdots$ & $0.075 \pm 0.020^{\cdots}$ & $0.81 \pm 0.34 \cdots$ & $0.011 \pm 0.002 \cdots$ \\
\hline \multicolumn{6}{|l|}{ Site } \\
\hline 1 & $4.19 \pm 0.21$ & $3.78 \pm 0.14$ & $0.585 \pm 0.028$ & $24.70 \pm 2.49$ & $0.061 \pm 0.004$ \\
\hline 2 & $3.72 \pm 0.26$ & $3.26 \pm 0.19$ & $0.615 \pm 0.040$ & $7.50 \pm 2.00^{\circ}$ & $0.011 \pm 0.003^{\circ}$ \\
\hline 3 & $2.12 \pm 0.30^{\circ}$ & $1.70 \pm 0.22^{\circ}$ & $0.557 \pm 0.029$ & $5.84 \pm 0.79^{\circ}$ & $0.015 \pm 0.002^{\circ}$ \\
\hline 4 & $2.56 \pm 0.21^{\circ}$ & $2.18 \pm 0.20^{\circ}$ & $0.647 \pm 0.022$ & $10.82 \pm 1.98^{\circ}$ & $0.014 \pm 0.006^{\circ}$ \\
\hline
\end{tabular}

drocarbons in the body tissues of Mytilus edulis are listed in Table 1, together with the seawater exposure concentrations for total hydrocarbons and $\mathrm{Cu}$. There was a marked increase in the tissue concentration of both toxicants, up to 20 -fold for total aromatic hydrocarbons and 8 -fold for $\mathrm{Cu}$. Concentrations of aromatic hydrocarbons in tissues of $\mathrm{H}$ dose mussels were ca $50 \%$ of those in the $M$ group, due to the shorter exposure period ( 3 wk following re-stocking of the $\mathrm{H}$ dose basin, compared to $15 \mathrm{wk}$ exposure for other groups). Also, mussels were sampled for chemical analysis 1 wk before physiological measurements were carried out. The concentrations of aromatic hydrocarbons in $\mathrm{H}$ dose mussels would have continued to increase significantly during the fourth week. Assum- ing a linear accumulation over this period gives a rate of $0.53 \mathrm{mg} \mathrm{kg}^{-1} \mathrm{~d}^{-1}$, resulting in an estimated aromatic hydrocarbon concentration of $14.2 \mathrm{mg} \mathrm{kg}^{-1}$ after $4 \mathrm{wk}$ exposure; a tissue concentration still below that of the $M$ exposed group (i.e. $22.8 \mathrm{mg} \mathrm{kg}^{-1}$ after $15 \mathrm{wk}$ ). This estimated rate of hydrocarbon uptake by $\mathrm{H}$ dose mussels would predict a tissue concentration of $24.9 \mathrm{mg}$ $\mathrm{kg}^{-1}$ after 7 wk exposure; this is in close agreement with the measured tissue concentration of $26.9 \mathrm{mg} \mathrm{kg}^{-1}$ after 7 wk exposure and just before the complete mortality of the first batch of $\mathrm{H}$ dose mussels. In contrast, the other groups ( $L$ and $M$ ) would have reached a near equilibrium state by $15 \mathrm{wk}$ and there would have been little further accumulation in the 16 th week prior to physiological measurement. For example, following an

Table 4. Mytilus edulis. Components of the energy budget and scope for growth $\left(\mathrm{J} \mathrm{g}^{-1} \mathrm{~h}^{-1}\right)$ in mussels exposed to 4 concentrations of petroleum hydrocarbons and copper in experimental mesocosm basins and in mussels collected from 4 sites in Langesundfjord (mean $\pm \mathrm{SE}, n=16$ ). Mesocosm mussels held in seawater from $40 \mathrm{~m}$ depth (POM $0.25 \mathrm{mg} \mathrm{l}^{-1}$ ), field mussels in water from $1 \mathrm{~m}$ (POM $0.66 \mathrm{mg} \mathrm{l}^{-1}$ )

\begin{tabular}{|c|c|c|c|c|c|c|}
\hline Source & $\begin{array}{c}\text { Energy } \\
\text { consumed, } \mathrm{C}\end{array}$ & $\begin{array}{c}\text { Energy } \\
\text { absorbed, A }\end{array}$ & $\begin{array}{l}\text { Energy } \\
\text { respired, } \mathrm{R}\end{array}$ & $\begin{array}{c}\text { Energy } \\
\text { excreted, U }\end{array}$ & $\begin{array}{l}\text { Scope for } \\
\text { growth, SFG }\end{array}$ & $\begin{array}{l}\text { Growth } \\
\text { efficiency }\end{array}$ \\
\hline \multicolumn{7}{|l|}{ Basin } \\
\hline C & $19.46 \pm 0.65$ & $7.78 \pm 0.26$ & $4.57 \pm 0.38$ & $0.32 \pm 0.02$ & $2.91 \pm 0.52$ & 0.37 \\
\hline L & $18.50 \pm 1.10$ & $7.40 \pm 0.44$ & $4.61 \pm 0.25$ & $0.28 \pm 0.02$ & $2.79 \pm 0.48$ & 0.38 \\
\hline$M$ & $16.05 \pm 0.79$ & $6.41 \pm 0.31$ & $5.03 \pm 0.39$ & $0.37 \pm 0.03$ & $1.02 \pm 0.46^{\circ}$ & 0.16 \\
\hline $\mathrm{H}$ & $3.62 \pm 0.34$ & 0.00 & $1.53 \pm 0.40$ & $0.01 \pm 0.03$ & $-1.54 \pm 0.42 \cdot$ & - \\
\hline \multicolumn{7}{|l|}{ Site } \\
\hline 1 & $63.62 \pm 3.12$ & $20.36 \pm 1.00$ & $11.88 \pm 0.57$ & $0.46 \pm 0.04$ & $7.99 \pm 1.04$ & 0.39 \\
\hline 2 & $56.52 \pm 3.90$ & $18.09 \pm 1.25$ & $12.46 \pm 0.82$ & $0.15 \pm 0.04$ & $5.49 \pm 1.29$ & 0.30 \\
\hline 3 & $32.28 \pm 4.56$ & $10.33 \pm 1.46$ & $11.31 \pm 0.60$ & $0.11 \pm 0.02$ & $-1.10 \pm 1.57^{\circ}$ & -0.10 \\
\hline 4 & $38.87 \pm 3.26$ & $12.44 \pm 1.04$ & $13.13 \pm 0.44$ & $0.22 \pm 0.04$ & $-0.90 \pm 1.07^{\circ}$ & -0.07 \\
\hline
\end{tabular}


apparently linear increase in tissue concentration over the initial 7 wk (25 Apr 86 to 13 Jun 86), mussels in L and $M$ basins were approaching a steady state at ca $80 \%$ of the levels at $15 \mathrm{wk}$.

\section{Fields sites in Langesundfjord}

Physiological responses of Mytilus edulis collected from the 4 sites in Langesundfjord are given in Table 3. Clearance rates of mussels from populations at Sites 3 and 4 , in the northern part of Langesundfjord near the sill at Brevik, were significantly lower than those of mussels from Sites 1 (reference) and 2. Clearance rates of mussels from Sites 1 and 2 were not significantly different from one another, and neither were those from Sites 3 and 4. Maximum and mean estimates of clearance rate are presented in Table 3; they show the same relationship along the 4 sites in Langesundfjord, the mean being consistently 80 to $90 \%$ of the maximum clearance rate. Mean absorption efficiency for all groups of mussels was $0.32 \pm 0.05 \mathrm{SE}$.

There were no significant population differences in the rates of oxygen consumption. Rates of ammonia excretion by mussels from Sites 2, 3 or 4 were all significantly lower than those for the reference population (Site 1). Consequently, the nitrogen quotients, i.e. the moles of nitrogen excreted per mole of oxygen consumed, were significantly lower for mussels from Sites 2,3 or 4

The physiological processes representing components of the balanced energy equation have been converted to energy equivalents and scope for growth, and growth efficiencies calculated for mussels from each field site (Table 4). Mussels from Sites 1 and 2 had positive scope for growth (SFG) values that were not significantly different, although mussels from Site 1 had slightly higher SFG. Mussels from Site 3 and 4 had significantly $(p<0.05)$ lower and negative SFG values and growth efficiencies; this indicated that the mussels from these 2 northern sites, nearer Brevik, were stressed. Body condition indices did not differ between the 4 field sites (Table 2).

Trace metal concentrations in the body tissues of Mytilus edulis from the 4 sites are presented in Table 5 .
There were relatively small increases in $\mathrm{Cu}, \mathrm{Fe}, \mathrm{Mn}, \mathrm{Cd}$ and $\mathrm{Pb}$ through Sites 1 to 4 . Tissue concentrations of selected aromatic hydrocarbons were quantified by means of GC-MS by Klungsøyr et al. (1988). These data have been simplified (Table 6) by grouping into 3 categories: low molecular weight (MW) aromatic hydrocarbons, low and medium MW aromatic hydrocarbons and total aromatic hydrocarbons (low + medium + high MW). They show a marked increase from Sites 1 to 4 , with a 3 -fold increase in the low MW fraction and a 9-fold increase in the high MW fraction. Concentrations of total polychlorinated biphenyls (PCB) accumulated in the tissues of $M$. edulis also increased by a factor of 3.6 from Sites 1 to 4 (Table 6).

\section{DISCUSSION}

Mytilus edulis from the experimental mesocosm basins showed a decline in scope for growth (SFG) with exposure to increasing concentrations of diesel oil and copper. SFG of $M$. edulis from the medium (M) exposure condition was significantly lower than in control (C) and low (L) exposure conditions, and SFG for the high $(\mathrm{H})$ exposure condition was significantly lower than in all other groups (Table 4). Measurement of major components of the energy budget demonstrated that the decline in the growth potential of mussels was primarily due to reduction in clearance or feeding rate (Table 3). Scope for growth values were low in mussels from all mesocosm basins due to the relatively low seston and POM concentrations in the water pumped from $40 \mathrm{~m}$ depth. This was also reflected in the low mass-specific respiration rates $150 \%$ of the Langesundfjord mussels) suggesting lower metabolic costs concomitant with a reduction in growth processes.

There was a clear and significant relationship between declining SFG and increasing $\mathrm{Cu}$ concentration in the tissues of Mytilus edulis ( $r=-0.98$ ), and between declining SFG and increasing concentration of aromatic hydrocarbons in the body tissues, at least for the $\mathrm{C}, \mathrm{L}$ and $\mathrm{M}$ mussels $(r=-0.85)$. The H group, however, had a lower aromatic hydrocarbon concentration in the tissues (14.2 $\mathrm{mg} \mathrm{kg}^{-1}$ at $4 \mathrm{wk}_{\text {; }}$ estimated)

Table 5. Mytilus edulis. Trace metal concentration ( $\mathrm{mg} \mathrm{kg}^{-1} \mathrm{dry} w \mathrm{t}$ ) in mussels from Langesundfjord (mean \pm semi-range, $n=2$ pools of 10 ind.)

\begin{tabular}{|cccccccc}
\hline Site & Date & Cu & Zn & Fe & Mn & Cd & Pb \\
\hline 1 & 11 Aug & $14.3 \pm 0.3$ & $193 \pm 17$ & $257 \pm 1$ & $25.5 \pm 0.4$ & $1.55 \pm 0.15$ & $3.45 \pm 0.65$ \\
2 & 13 Aug & $16.6 \pm 1.3$ & $148 \pm 5$ & $308 \pm 15$ & $60.1 \pm 1.0$ & $2.47 \pm 0.14$ & $6.55 \pm 0.30$ \\
3 & 12 Aug & $16.5 \pm 0.5$ & $148 \pm 21$ & $581 \pm 1$ & $38.0 \pm 4.7$ & $2.72 \pm 0.23$ & $6.50 \pm 0.10$ \\
4 & 14 Aug & $17.0 \pm 0.6$ & $150 \pm 23$ & $398 \pm 19$ & $72.0 \pm 1.9$ & $2.61 \pm 0.09$ & $7.85 \pm 0.80$ \\
\hline
\end{tabular}


Table 6. Mytilus edulis. Concentrations ( $\mathrm{mg} \mathrm{kg} \mathrm{kg}^{-1}$ dry mass) of selected aromatic hydrocarbons (PAH) and total PCB in mussels from 4 Langesundfjord sites (mean \pm semi-range, $n=2$ pools of 10 ind.). Low MW PAH (naphthalene, C1 to C3 naphthalenes, phenanthrene, $\mathrm{C} 1$ to $\mathrm{C} 2$ phenanthrenes); low + med MW PAH (low MW PAH + anthracene, dibenzothiophene, C1 to C3 dibenzothiophenes); 'total' PAH (low + med MW PAH + fluoranthene, pyrene, benzla]anthracene, chryrsene, benz[b + k]fluoranthene, benz[e]pyrene, benz[a]pyrene, perylene)

\begin{tabular}{|cccccc|}
\hline Site & Date & Low MW PAH & Low + med MW PAH & 'Total' PAH & Total PCB \\
\hline 1 & $11 \mathrm{Aug}$ & $0.725 \pm 0.024$ & $0.933 \pm 0.035$ & $2.242 \pm 0.079$ & $0.076 \pm 0.006$ \\
2 & $13 \mathrm{Aug}$ & $1.238 \pm 0.013$ & $1.680 \pm 0.006$ & $5.868 \pm 0.067$ & $0.178 \pm 0.013$ \\
3 & $12 \mathrm{Aug}$ & $1.907 \pm 0.093$ & $2.626 \pm 0.120$ & $11.430 \pm 0.602$ & $0.222 \pm 0.017$ \\
4 & $14 \mathrm{Aug}$ & $2.355 \pm 0.319$ & $3.618 \pm 0.568$ & $15.451 \pm 1.411$ & $0.276 \pm 0.022$ \\
\hline
\end{tabular}

compared to the $\mathrm{M}$ group $\left(22.8 \mathrm{mg} \mathrm{kg}^{-1}\right)$, due to a combination of the shorter period of exposure (i.e. $4 \mathrm{wk}$ compared to $16 \mathrm{wk}$ ) and the form of the relation between rate of uptake and the concentration of hydrocarbons in the water. Although $\mathrm{H}$ mussels had a higher rate of hydrocarbon uptake, $0.53 \mathrm{mg} \mathrm{kg}^{-1} \mathrm{~d}^{-1} \mathrm{com}$ pared to 0.35 and $0.10 \mathrm{mg} \mathrm{kg}^{-1} \mathrm{~d}^{-1}$ for $\mathrm{M}$ and $\mathrm{L}$ mussels respectively, over the initial $7 \mathrm{wk}$ of exposure, rate of uptake was linearly related to the log concentration of hydrocarbons in the water. In contrast, rate of uptake of Cu over the initial $7 \mathrm{wk}$ was directly proportional to the concentration of $\mathrm{Cu}$ in the water $\left(\mathrm{H}: 0.9 \mathrm{mg} \mathrm{kg}^{-1} \mathrm{~d}^{-1}\right.$, M: $0.2 \mathrm{mg} \mathrm{kg}^{-1} \mathrm{~d}^{-1}$, L: $\left.0.05 \mathrm{mg} \mathrm{kg}^{-1} \mathrm{~d}^{-1}\right)$. Consequently, after $4 \mathrm{wk}$ of exposure to the $\mathrm{H}$ condition the replacement batch of mussels had accumulated $\mathrm{Cu}$ in their tissues to concentrations in excess of $M$ mussels exposed for $16 \mathrm{wk}$. The concentration of $\mathrm{Cu}$ in the tissues of $\mathrm{H}$ mussels was $59 \mathrm{mg} \mathrm{kg}^{-1}$, and this was precisely the critical level of accumulated $\mathrm{Cu}$ which Martin (1979) found to be ultimately lethal to $M$. edulis, regardless of the concentration of $\mathrm{Cu}$ in the water or exposure time.

Previous studies on the separate effects of $\mathrm{Cu}$ and petroleum hydrocarbons on clearance rate and growth of Mytilus edulis suggest that the effects observed in the present study represent a relatively complex interaction between $\mathrm{Cu}$ and petroleum hydrocarbons over the range of concentrations studied. Field studies (Widdows et al. 1987) and mesocosm studies (Widdows et al. 1985) have demonstrated that petroleum hydrocarbons, particularly aromatic hydrocarbons, accumulated in the tissues of $M$. edulis depress clearance rate and SFG over a wide range of concentrations, representing more than 3 orders of magnitude, with no evidence of a threshold effect. In contrast to petroleum hydrocarbons, $\mathrm{Cu}$ appears to exert sublethal effects on feeding and growth rates of $M$. edulis over a relatively narrow range of water concentrations (less than 1 order of magnitude) with a threshold of effect at ca 5 to $10 \mu \mathrm{g}$ $\mathrm{Cu} \mathrm{l}^{-1}$ and a marked inhibition at $20 \mu \mathrm{g} \mathrm{Cu} \mathrm{l}^{-1}$ (Manley 1983, Calabrese et al. 1984, Manley et al. 1984, Redpath 1985). Therefore it appears that $\mathrm{Cu}$ concentrations in $L$ and $M$ conditions were below the threshold of effect, and that the extent of the decline in clearance rate (L: $5 \%$, M: $20 \%$; approximately) and SFG, measured in $\mathrm{L}$ and $\mathrm{M}$ mussels, can be entirely explained by the hydrocarbon concentrations. For example, previous studies (Widdows et al. 1985) have demonstrated that mussels exposed to diesel oil concentrations of $30 \mu \mathrm{g}$ $\mathrm{l}^{-1}$, equivalent to the $\mathrm{M}$ condition, reduced their clearance rates by about $30 \%$.

In contrast to $L$ and $M$ mussels, the marked reduction $(80 \%)$ in clearance rate and the negative SFG recorded in $\mathrm{H}$ mussels cannot be explained by the action of either petroleum hydrocarbons or copper on their own, but by a cumulative effect of these 2 pollutants. Previous studies have shown that chronic exposure to $130 \mu \mathrm{g}$ $\mathrm{l}^{-1}$ of diesel oil only reduced the clearance rate of Mytilus edulis by $60 \%$, faeces continued to be produced and mussels survived at least 9 mo (Widdows et al. 1985), whereas exposure to $20 \mu \mathrm{g} \mathrm{Cu} \mathrm{l^{-1 }}$ caused sharp adduction of valves (Davenport \& Manley 1978), reduction of clearance rate by $50 \%$ (Manley 1983) and cessation of shell growth in small (15 mm) mussels (Redpath 1985). Therefore a simple proportional additive response to $120 \mu \mathrm{g}$ petroleum hydrocarbons $\mathrm{l}^{-1}$ and $20 \mu \mathrm{g} \mathrm{Cu} 1^{-1}$ appears to explain the observed $80 \%$ reduction in clearance rate of $\mathrm{H}$ mussels (i.e. $50 \%$ reduction following, or in addition to, $60 \%$ reduction, resulting in a total reduction of $80 \%$ ). Recently, Stromgren (1986) recorded a similar 'proportional additive' response in shell growth of $M$. edulis exposed to various combinations of oil and $\mathrm{Cu}$. However, the effects of $\mathrm{Cu}$ and oil were stated as being antagonistic and not recognized as simply additive on a proportional basis.

This apparently additive and predictable relationship is based on water exposure concentrations. There is still a discrepancy between the effects on clearance rate and the concentration of aromatic hydrocarbons in the tissues of $\mathrm{H}$ mussels; at 4 wk hydrocarbon concentrations in the tissues had not attained a steady state, at least not in whole mussels. This may be explained by differences in rates of uptake and loss of hydrocarbons by the various body tissues. Riley et al. (1981) and 
Widdows et al. $(1983,1985)$ have shown that gills of bivalves accumulate and depurate aromatic hydrocarbons at significantly faster rates than other body tissues. Gill tissues of $\mathrm{H}$ mussels may therefore be in near equilibrium with the hydrocarbon concentration in the water, thus inducing a marked reduction in the clearance rate.

Mussels collected from the field sites along a pollution gradient in Langesundfjord also showed marked declines in clearance rate and scope for growth (Table 4) with increasing body burdens of polyaromatic hydrocarbons and PCBs (Table 6). The negative relation with $\mathrm{SFG}$ is described by the following regression equation $(r=-0.6)$

$$
\operatorname{SFG}\left(\mathrm{J} \mathrm{g}^{-1} \mathrm{~h}^{-1}\right)=13.0-5.17 \log (\mathrm{PAH}+\mathrm{PCB})
$$

In contrast to the nearly 7 -fold increase in organic contaminants, metal concentrations in the tissues of Mytilus edulis showed little variation along the length of Langesundfjord (Table 5) and were not sufficiently elevated to cause the observed effects on SFG. Copper concentrations were comparable to tissue concentrations of the mussels from the $\mathrm{L}$ mesocosm basin (Table 1), and slightly higher (20\%) than in mussels from the Tamar estuary, SW England (Widdows et al. 1984). Tissue concentrations of other toxic metals, such as $\mathrm{Cd}$ and $\mathrm{Pb}$, were ca $50 \%$ of the values for mussels in the Tamar estuary.

Previous field and laboratory studies have demonstrated that clearance rate and SFG of Mytilus edulis are very responsive to organic toxicants including petroleum hydrocarbons (Widdows et al. 1982, 1985) and PCBs (Martin 1985). Recent experiments have also established that there are quantitative and predictable relationships between chemical structure/physicochemical properties of a range of organic toxicants (low and medium MW hydrocarbons) and their sublethal biological effects, namely a reduction in the clearance rate of $M$. edulis (Donkin \& Widdows 1986). The main conclusion of these quantitative-structure activity relations (QSARs) are that organic toxicants of widely different chemical structure and physico-chemical properties, up to a molecular size toxicity cut-off, have a similar toxicity when expressed in terms of tissue concentrations, and the differences in toxicity expressed on a water concentration basis are largely due to differences in bioaccumulation. These findings provide an explanation for the previously described negative relation between SFG and log concentration of low and medium MW aromatic hydrocarbons in the body tissues of $M$. edulis from various oil-contaminated sites (Moore et al. 1987. Widdows et al. 1987). Therefore, with the appropriate chemical analytical data for tissue residues it should be possible to predict biological consequences in terms of SFG. If the observed reduc- tion in SFG is greater than predicted from the measured body burden and there is consequently an increase in the slope of the relationship, then this would suggest action from additional toxicants, and that further chemical analyses of body tissues for previously unidentified environmental contaminants should be carried out.

This appears to be the situation for the Langesundfjord pollution gradient. The reduction in clearance rate and SFG was greater than could be explained by the contaminants analysed to date (i.e. selected aromatic hydrocarbons, PCBs and selected metals). It is known that other toxicants are entering Langesundfjord from Frierfjord ( $\mathrm{Hg}$, pentachlorobenzene, hexachlorobenzene, octachlorostyrene; Skei 1981). However, the contribution that these toxicants - and other unidentified toxicants within the 'unresolved complex mixture' (UCM) of the GC analysis - make towards the total body burden is unknown. In the light of the physiological measurements it might be profitable to examine these chemical aspects further. Also, the observed effects on clearance rate and SFG of mussels at Sites 3 and 4 cannot be explained by any differences in natural environmental factors, such as temperature, salinity, suspended particulates and $\mathrm{pO}_{2}$ along the pollution gradient. Not only were the differences in these factors relatively small and/or within the range of compensation or independence (Widdows 1985a), but also the physiological responses were measured under standardized conditions at Solbergstrand.

In conclusion, physiological responses of Mytilus edulis - such as clearance rate and scope for growth showed a significant and generally predictable response to a pollution gradient both in the mesocosm basins and in the field. This approach to measuring the adverse biological effects of pollutants illustrates several important attributes. (1) It demonstrates sensitivity to environmentally realistic levels of pollution. (2) It reflects a quantitative and predictable relation with the concentrations of toxicants in the body tissues. (3) It represents a general response to the total pollution stimulus, which can also gain some specificity through understanding of the relative toxic effects of individual pollutants or classes of pollutants on components of the mussel's energy budget. (4) Feeding and growth responses are readily interpretable in terms of significant detrimental effects on the individual, as well as having important consequences at the population level

\section{LITERATURE CITED}

Bakke, T., Follum, O. A., Moe, K. A., Sorensen, K. (1988). The GEEP Workshop: mesocosm exposures. Mar Ecol. Prog. Ser. $46: 13-18$ 
Bayne, B. L., Newell, R. C. (1983). Physiological energetics of marine molluscs. In: Wilbur, K. M., Salenddin, A. S. M. (eds.) The Mollusca, Vol. 4, Physiology, Part 1. Academic Press, London, p. 407-515

Bayne, B. L., Worrall. C. M. (1980). Growth and production of mussels Mytilus edulis from two populations. Mar. Ecol Prog. Ser. 3: $317-328$

Calabrese, A., Maclnnes, J. R., Nelson, D. A., Greig, R. A. Yevich, P. P. (1984). Effects of long-term exposure to silver or copper on growth, bioaccumulation and histopathology in the blue mussel Mytilus edulis. Mar. environ. Res. 11: $253-274$

Conover, R. J. (1966). Assimilation of organic matter by zooplankton. Limnol. Oceanogr. 11:338-354

Davenport, J., Manley, A. (1978). The detection of heightened sea-water copper concentrations by the mussel Mytilus edulis. J. mar. biol. Ass. U.K. 58: 843-850

Donkin, P., Widdows, J. (1986). Scope for growth as a measurement of environmental pollution and its interpretation using structure-activity relationships. Chemy Ind. 21: $732-737$

Follum, O. A., Moe, K. A. (1988). The GEEP Workshop: field sampling. Mar. Ecol. Prog. Ser. 46: 7-12

Gilfillan, E. S., Vandermeulen, J. H. (1978). Alterations in growth and physiology in chronically oiled soft-shelled clams, Mya arenaria, chronically oiled with Bunker C from Chedabucto Bay, Nova Scotia, 1970-1976. J. Fish. Res. Bd Can. 35: 630-636

Hilbish, T. J. (1986). Growth trajectories of shell and soft tissues in bivalves: Seasonal variation in Mytilus edulis L. J. exp. mar. Biol. Ecol. 96: 103-113

Klungsayr, J., Wilhelmsen, S., Westrheim, K., Saetvedt, E., Palmork, K. H. (1988). The GEEP Workshop: organic chemical analyses. Mar. Ecol. Prog. Ser. 46: 19-26

Manley, A. R. (1983). The effects of copper on the behaviour, respiration, filtration and ventilation activity of Mytilus edulis. J. mar biol. Ass. U.K. 63: 205-222

Manley, A. R., Gruffydd, Ll.D., A.lmada-Villela, P. C. (1984) The effect of copper and zinc on the shell growth of Mytilus edulis measured by a laser diffraction technique. $J$. mar biol. Ass. U.K. 64: 417-427

Martin, J. L. M. (1979). Schema of lethal action of copper on mussels. Bull. environ. Contam. Toxicol. 21. 808-814

Martin, M. (1985). State mussel watch: Toxics surveillance in California. Mar. Pollut. Bull. 16: 140-146

Moore, M. N., Livingstone, D. R., Widdows, J. (1988). Hydrocarbons in marine molluscs: biological effects and ecological consequences. In: Varanasi, U. (ed.) Aromatic hydrocarbon metabolism by aquatic organisms. CRC Press Inc. Boca Raton, Florida (in press)
Redpath, K. J. (1985). Growth inhibition and recovery in mussels (Mytilus edulis) exposed to low copper concentrations. J. mar biol. Ass. U.K. 65: $421-431$

Riley, R. T., Mix, M. C., Schaffer, R. L., Bunting, D. L. (1981). Uptake and accumulation of naphthalene by the oyster, Ostrea edulis, in a flow-through system. Mar Biol. 61 $267-276$

Skei, J. (1981). The entrapment of pollutants in Norwegian fjord sediments - a beneficial situation for the North Sea Spec. Publs int. Ass. Sediment. 5: $461-468$

Stromgren, $T$ (1986). The combined effects of copper and hydrocarbons on the length growth of Mytilus edulis. Mar. environ. Res. 19: 251-258

Widdows, J. (1983). Field measurements of the biological impact of pollutants. In: Su, J. C., Hung, T C. (eds.) Proceedings of a Pacific Regional Workshop on the Assimilative capacity of the oceans for man's wastes. Scope/ICSU Academia Sinica, Taipei, Republic of China, p. $111-129$

Widdows, J. (1985a). Physiological responses to pollution. Mar Pollut. Bull. 16: 129-134

Widdows, J. (1985b). Physiological measurements \& Physiological procedures. In: Bayne et al. (eds.) The effects of stress and pollution on marine animals. Praeger, New York, p. 3-45 \& 161-178

Widdows, J., Bakke, T., Bayne, B. L., Donkin, P., Livingstone, D. R., Lowe, D. M., Moore, M. N., Evans, S. V., Moore, S. L. (1982). Responses of Mytilus edulis on exposure to the water accommodated fraction of North Sea oil. Mar. Biol. 67: $15-31$

Widdows, J., Donkin, P. Evans, S. V. (1985). Recovery of Mytilus edulis L. from chronic oil exposure. Mar. environ. Res. 17: 250-253

Widdows, J., Donkin, P., Salkeld, P. N., Cleary, J. J., Lowe, D M., Evans, S. V., Thompson, P. E. (1984). Relative importance of environmental factors in determining physiological differences between two populations of mussels (Mytilus edulis). Mar. Ecol. Prog. Ser. 17: 33-47

Widdows, J., Donkin, P., Salkeld, P. N., Evans, S. V (1987). Measurement of scope for growth and tissue hydrocarbon concentrations of mussels (Mytilus edulis) at sites in the vicinity of the Sullom Voe oil terminal: a case study. In Van den Brink, W. J., Kuiper, J. (eds.) Fate and effects of oil in marine ecosystems. Martinus Niijhof, Dordrecht, p. $269-277$

Widdows, J., Moore, S. L., Clarke, K. R., Donkin, P. (1983). Uptake, tissue distribution and elimination of $\left[1-{ }^{14} \mathrm{C}\right]$ naphthalene in the mussel Mytilus edulis. Mar. Biol. 76: 109-114 